\title{
Lost to Presence: The Entanglements of Writing, Protestant Christianity, and Empire in the $19^{\text {th }}$-Century Southern Africa
}

\author{
Sepetla Molapo \\ sepetla.molapo@up.ac.za
}

\begin{abstract}
This essay takes interest in a dialectical relationship between writing as affirmation and writing as a system of codification. It explores this dialectic as it relates to the interaction between Sotho-speaking communities and Protestant Christian missionaries in the $19^{\text {th }}$-century Southern Africa. It shows that this dialectical relationship dissolves truth as a construct of writing as affirmation because it is informed by an ontology of force that conceives of truth (Christian truth in this case) as an outcome of victory over an adversary. This ontology of force, in which Christianity participates, is a consequence of a modern metaphysics that splits individual and divine will. Cut off from participation in divine will, the autonomous will of Protestant Christian missionaries became the basis for organizing the world of the $19^{\text {th }}$-century Sotho speakers. This opened doors for Christianity to participate in the broader imperial project of the racial subordination of colonized people that Sotho speakers resemble. The consequence of this was not only the delegitimization of personhood as a construct of indigenous African religion, but also the introduction of conceptions of personhood that partook of race and racism.
\end{abstract}

Keywords: Writing, codification, affirmation, Christianity, Southern Africa 


\section{Introduction}

This essay concerns itself with the dialectical ${ }^{1}$ relation between writing as codification and writing as affirmation in the $19^{\text {th }}$-century Southern Africa. It is concerned with writing as a form of organizing the world under conditions of empire and detects in the expanding Christian missionary enterprise a vehicle for ordering and organizing the colonized world in line with imperial aspirations. Christian missions participate in the consolidation of empire because conversion to Christianity, on the part of the subjects of colonization, implies the acceptance of religion as a construct of processes of codification. To convert subjects of colonization to Christianity implies imposing an order where it is understood to be in deficit. This is particularly so if we consider that the phenomena of religion in the $19^{\text {th }}$-century Southern Africa, as elsewhere in Africa, was transmitted via memory. Consequently, it lacked the fixity and homogeneity that accompany the order that writing tries to impose. In the context of $19^{\text {th }}$-century Christian missions, therefore, writing can be regarded as an attempt to order and organize memory in line with religion as a construct of the Enlightenment (cf. Asad 1993). Writing as codification must be understood as a specific area within the broader process of the constitution of Africa as a paradigm of difference that Mudimbe (1988; 1994) outlines and is apparent in the study of law under conditions of imperial rule (Kolsky 2005). Writing as affirmation, on the other hand, is a species of discourse on the gift that is manifest in Mauss (1954), Derrida (Shepherd 2014), and Milbank (2003), among others. If writing as codification is about the fixing and homogenization of the world, so as to realize universal institutions and practices, writing as affirmation points to the acknowledgement of particularity, plurality, and the difference that codification opposes. It regards these as cornerstones in building an inclusive and humane world.

This essay locates the tussle between writing as codification and writing as affirmation within a context of the interaction between Sotho speakers and Protestant Christian missionaries in Southern Africa during the

1 The dialectic is used here with reference to a way of dealing with contradictions, oppositions, and inconsistencies in the search for the truth about God under conditions of colonization. This tradition is often associated with Plato, Kant, Hegel, as well as Marx, among others. However, while using the themes associated with the thinking of these figures, the essay does not side with anyone of them because none of them applied dialectics to circumstances peculiar to colonization. 
$19^{\text {th }}$ century. It shows that the work of translation by Protestant Christian missionaries furnished an arena for the contest of writing as codification and writing as affirmation. The $19^{\text {th }}$-century interaction between Sotho speakers and Protestant Christian missionaries mainly entered the academic discourse in the $20^{\text {th }}$ century and did so via the work of Christian theologians who were concerned with the Africanization of Christianity which they regarded as alienating the African experience (Setiloane 1986; 1976; Manyeli 1995). They shared this concern of Africanizing Christianity with fellow Christian theologians elsewhere in the African continent (Mbiti 1990; Magesa 1997), a concern that has a longer genealogy going back to the work of Kagame (1956) and Temples (1945), among others. While the intellectual work of Africanizing Christianity has succeeded in making the indigenous African culture and languages visible in both the academy and in scholarship, the Christian lenses that inform this scholarship tend to limit the potential of the African culture to articulate its own independent thought apart from Christianity. Thus, while this scholarship has been valuable in the sense that it furnishes the possibility of imagining a Christianity that is African and that challenges Western impositions that came with $19^{\text {th }}$-century European missionaries, it can still be accused of limiting the intellectual potential of African culture by perpetually subjecting it to a Christian gaze. While this interaction has been cast broadly on the basis of interest in the Africanization of Christianity, very little or no effort has been made to cast this interaction on the basis of the framework of empire. The consequence of this has been the neglect of codification as a strategy that performs the work of empire. Although codification is beginning to surface in recent scholarship (Molapo 2019), it is not explicitly located within the framework of empire. This is the neglect that this essay tries to address. The essay is conceptual and explorative and relies on a reading of both the archives of Protestant Christian missionaries and the indigenous African religion.

\section{The Displacement of Writing by Writing}

The tussle between writing as codification and writing as affirmation is manifest in the hostility that Protestant Christian missionaries (and other Christian missionaries) had towards a belief in the ancestors. This tussle therefore articulates around an opposition to the idea that dead others (specifically, dead others directly related to the living by blood) are an 


\section{Sepetla Molapo}

affirmation of the experience of the world of the living. Protestant Christian missionaries oppose the idea that the experience of the world of the living cannot be thought of in the absence of others who are lost to death. Those who are lost to death are sacred (set apart) because death is the habitation of divinity (i.e., divinity is thought of in relation to loss) (cf. Molapo 2019). To die and take one's place among the dead is to always come before the living. The dead as such have priority of place over the living. The affirmation of the dead others as what comes before (and what is constitutive of the experience of the life of the living) got delegitimized in the $19^{\text {th }}$ century because Christianity foregrounded writing as a system of codification in its appropriation of local understandings of divinity. This process delegitimized the understanding of the dead others as an affirmation of the experience of the world of the living because it positioned what is available and present (and not what is lost) as ground for the experience of the world by the living. In place of writing as affirmation (of what comes before because of loss), it placed writing as a system of codification (i.e., writing as a process of making available what ought to be lost to death).

The idea that the dead others (or loss) furnish the condition of possibility of experience of the living (or that what comes before is an affirmation of what is), is one of the key themes of indigenous African religion and must be appreciated in relation to religious constructions of time. These constructions of time pertain to time as something that is available to emotionality and time as a reality entirely lost to emotionality. The first dimension of time is evident within the cult of balimo (the ancestors). Time here depicts a connection to emotionality because it signals the link between the living and the departed loved ones (i.e., the intimacy of memory and loss). This connection of memory and loss is of paramount importance because it speaks to the coconstitution of affirmation and experience. This is to say that at some stage affirmation itself was once an experience constituted via loss (the loss to death of loved ones) and as it became experience lost to death, it became constitutive of experience. Therefore, affirmation as such is never fundamental or foundational because it never arrives at a closure. Affirmation always already presupposes something else that comes before (in this case, others lost to death).

It is significant to also note that the connection of memory and loss (i.e., death) does not only speak to the coconstitution of affirmation and experience, but that this coconstitution denotes the connection between time 
and space. That is, the coconstitution of affirmation and experience occurs in space and time. It is not an abstract or imaginary occurrence. It is of crucial importance therefore to realize that the coconstitution of affirmation and experience is impossible outside of others whose arrival is expected in the future (i.e., outside of the interconnection of memory, loss, and reception). This expectation of others (whether they are received through birth or as strangers), positions experience as having not only a past but also a future towards which it is directed. It is precisely this interconnection of memory, death, and reception that those writing on indigenous African religion are missing (Mbiti 1990; Setiloane 1986; Magesa 1997).

The second dimension of time, viz, of time as a reality entirely lost to emotionality $^{2}$, is apparent in the cult of the one-legged one (Setiloane 1986) who is often interpreted as the figure of molimo or African divinity. Unlike the dead others (the ancestors), the one-legged one appears to be someone other than human. This is the one who comes before but is not human and this absence of personhood is apparent in the very reference to this one as the one-legged one. To say that the one-legged one is someone other than human, is to situate affirmation before personhood and to regard personhood as always deriving its affirmation from a moment or event that presents personhood with its own affirmation. Reference to the one-legged one therefore breaks the endless chain of affirmations that derive from a lost personhood. This break points to personhood as deriving its affirmation from a before, an event that is outside of personhood itself. However, this affirmation that is other than human, is not a closure because it presupposes something that comes before. The indigenous African religion in its $19^{\text {th }}$-century Sotho expression does not seem to say what it is that comes before what is otherwise than human but leaves the question of the before what is other than human open.

The consequence of the loss of time to emotionality manifest in the cult of the one-legged one, is the rupture of memory and loss (i.e., loss of loved others). This rupture is of crucial importance because it suggests the possibility of speaking about experience in relation to a different modality of

2 Emotionality is used here to denote the availability of life to an embodied experience. It is not used, for instance, in the manner found among thinkers of negritude where it is in opposition to reason. The idea of affect is perhaps closest to the way in which emotionality is used in this essay. 


\section{Sepetla Molapo}

temporality which is outside of the reference to the past, the present, and the future. This is a modality of temporality that approaches experience on the basis, not of beginnings and ends, but of one that seeks an exit from beginnings and ends and therefore from time as we know it. The concern of this modality of temporality appears to be with what comes before time as we know it and time as available to emotionality and language. This is where the cult of the one-legged one appears to situate the conversation about the subject matter of experience (i.e., the experience of personhood). It points to something else (a before) that accords this experience with its condition of possibility - the thing that makes beginnings and ends possible in the first place and the thing without which beginnings and ends are incomprehensible. This is where the richness of the cult of the one-legged one becomes apparent. It creates room for thinking about experience in relation to a more originary form of loss that time, as we know it, presupposes (i.e., outside of the interconnection of memory, loss, and reception). Here we are in the realm of the affirmation that comes not with (lost) personhood, but with what is otherwise than personhood (the thingness of life).

That the one-legged one (the figure of molimo) points to a different modality of temporality outside time as available to emotionality and language, is evident in an examination of the Sotho language structure. In its classification of nouns, the Sotho language structure puts persons in the first class of nouns (Mokoena 1998:71). This can be regarded as a class of nouns signaling the availability of time to emotionality and language because logically it is a class of nouns depicting persons who are beings of emotionality and language. Molimo, however, belongs to the third category which is not a category of nouns depicting persons, but one that depicts things. Moholi (mist) and mose (dress) are examples of nouns in this category. Seemingly, this is a category of things without emotionality and language. This is to say, it is a category of things that neither possesses emotionality nor language. The distinction therefore between time as available to emotionality and language, and time as lost to emotionality and language, appears to be deeply embedded in the Sotho language structure itself. One could argue as a result that the notion of molimo as affirmation is one that the Sotho language structure confirms. It is precisely the idea of molimo as a construct of a structure of affirmation that the contemporary epoch has forgotten. This epoch has forgotten molimo as what is prior to time 
as available to emotionality and language and as what makes time as available to emotionality and language possible in the first place.

The constitution of personhood as something that always already points to something else other than itself and as something that derives its worth from an elsewhere that, in the ultimate end, furnishes the condition of possibility of questioning time as we know it, got lost with the introduction of Christianity in Southern Africa in the $19^{\text {th }}$ century, as it did elsewhere in the African continent. It specifically got lost with the translation by the Christian missionaries of molimo as the Christian God. The process of the translation of molimo as the Christian God foregrounds writing as a system purely of codification. The consequence of this process is the extraction of molimo from its passage (and therefore from loss) and context because it is as a system of codification that writing is opposed to loss. It is as a system of codification that writing makes available what passage and loss claim and claim as constitutive. Writing as a result freezes life in space. It is this freezing of life in space that generates a crisis for personhood as a construct of indigenous African religion in the $19^{\text {th }}$ century because it introduces an ontology that functions primarily to deny difference. This denial of difference becomes apparent with the elevation of race and racism as defining features of the colonial modernity.

The process of the translation of molimo as the Christian God (i.e., the process that foregrounds writing as codification) is evident in the writings of a number of Christian missionaries working among Sotho speakers in the $19^{\text {th }}$ century. These include John Moffat, Eugene Casalis, and Samuel Broadbent. We focus on this process with specific reference to John Moffat because he was, according to Setiloane (1986), senior to both Casalis and Broadbent, while younger Christian missionaries tended to rely on his translation work. In translating the term 'molimo' as the Christian God, Moffat makes a set of interesting observations which point to a different modality of temporality than that assumed by Christianity. First, he states that the Sotho language structure (Setswana in this case) does not permit of molimo to be referred to as a person (a being). This is because in the classification of nouns, molimo belongs to the third category of nouns, which is the category denoting things and not persons (i.e., beings) (Moffat 1842:261). Second, that molimo is not a being, he says, is manifest in reference by the local populations to molimo as 'selo' - a thing. Third, as 'selo' - a thing - molimo is understood to reside in the underworld, the belly of the earth. Having 
carefully made these observations, Moffat would nonetheless proceed to extract molimo from this metaphysics and constitute molimo as the Christian God. By so doing he dislodged the $19^{\text {th }}$-century Sotho speakers from their own epistemological paradigm into a Christian and colonial one.

The direct consequences of this project are that first, molimo becomes a father and as father molimo ceases to be 'selo'. This is because by becoming a father, molimo becomes a being and acquires personhood. Molimo becomes a he (male person) and ceases being the great 'it' (Mbiti 1990; Moffat 1842:261). It is as father and the figure of the Christian God that molimo's residence moves from the underworld to heaven (above). The direct result of this is the introduction of a European and Christian form of patriarchy that dispenses with patriarchy as a construct of the $19^{\text {th }}$-century Sotho cultural forms (Molapo 2019). The indirect result of this revolutionary move is that this retreat into personhood by the divinity, elevates the present sense of time and gives it priority over time as always already lost to emotionality. This is because this move makes molimo available to language in which case molimo becomes the cornerstone of an orientation that has the mapping of the world and reality as its chief preoccupation. Molimo becomes the cornerstone of an orientation to the present sense of time because it is as written that he becomes the Christian God. It is writing that performs the task of constituting molimo as the Christian God. Molimo becomes the Christian God because writing as a system of codification constitutes him as such. Writing removes molimo from its location in the great eternal passage (permanent loss) and makes molimo subject to codification (in which case molimo becomes available in the here and now).

By casting molimo as written and as the Christian God (i.e., as the figure of presence ${ }^{3}$ ), the Christian missionaries foreclose the possibility of thinking about personhood (i.e., the experience of being human) outside of time as available to emotionality and language. They shut the rupture between memory and loss which is crucial to the questioning of the authority of the present sense of time in the definition of personhood. This surrenders personhood to the authority of the present sense of time in which case it emerges as a construct of ontotheology. As a construct of ontotheology, it is

3 Presence is used broadly here to denote a move towards a Christian ontology that opposes the priority of what is otherwise than presence. The unintended consequence of this is an opposition to difference. 
no longer concerned with others who came before (i.e., with loss as constitutive of experience). What remains of it is only an anticipation of reunion with others (i.e., saints in the aftermath of the Day of Judgment) and therefore carries an orientation to the future. If there is anything that the era that begins with the arrival of Christian missionaries in $19^{\text {th }}$-century Southern Africa did, it was the repositioning of personhood as the work purely of presence as a construct of Christianity. As the Christian God, molimo substitutes for the constitutive role of others and becomes the foundation for the new experience of personhood that arises with the localization of Christianity. This opens the door to the possibility of speaking about personhood in essentialist terms because writing positions molimo as having nothing before him (i.e., as the Alpha and the Omega). The implication of Christianity in race and racism becomes apparent in this move. This is because the choice for a modality of temporality that fixes life in space in the imagination of localized Christianity, is a choice for ethnocentrism. It is a choice for the organization of the world of $19^{\text {th }}$-century Sotho speakers in line with imperial and colonial aspirations in which case they have become part of a universal community of believers. That this community, however, is born out of a negation of difference and is therefore a racist enterprise geared towards assimilation, should be apparent.

\section{The Work of Forgetting}

The displacement of the theme of loss from imaginations of personhood or the experience of being a person, which accompanies the positioning of molimo as the figure of presence, finds concrete expression in Christian texts written in local languages (Sotho languages in this case). This is to say that the emerging Christian discourse that positioned molimo as the figure of presence, found anchor in texts that $19^{\text {th }}$-century Sotho speakers could access in their own languages. If we consider that language is who we are (Mignolo 2003:669) and not just an aspect of who we are, then we realize that these texts facilitate a process of the embodiment of molimo as the figure of presence and the dismissal of loss as constitutive of personhood. These texts do not just aim to colonize the mind but seek to capture the embodied experience of the $19^{\text {th }}$-century Sotho speakers. Those who, like Ngũgĩ (1986), regard colonization as a phenomenon that can be spoken of in relation to the 


\section{Sepetla Molapo}

capture of the mind, are missing out on the extent to which it is, in essence, a capture of the whole person. These texts do not just seek to communicate molimo as the figure of presence, but also function as instruments of forgetting. This is the forgetting of writing as affirmation and divinity as something other than presence. This section wants to pay attention to this process with reference to the Lord's Prayer.

The process of locating molimo as the figure of presence in texts meant for consumption by $19^{\text {th }}$-century Sotho speakers, is apparent in a conversation between Broadbent and some Barolong men in his company (Broadbent said that these men were his servants). In this conversation, Broadbent tried to communicate the Lord's Prayer that he had translated into Serolong, the Sotho dialect of the group of men who were in his company. He began with the first line of the Lord's Prayer, 'Our Father who is in heaven' and then paused to ask his interlocutors who this Father is to whom the Lord's Prayer refers. To his surprise, none of these men knew to whom the Father in the Lord's Prayer referred - this includes those who regularly attended Christian services. However, when he rephrased the question and asked who the origin and source of all things is, all exclaimed together and said 'madeemo' (molimo) (Broadbent 1865:81). Of course, Broadbent argues that the fact that these men had never heard of a Father in heaven is proof of their ignorance and by that token, their backwardness. This claim to backwardness, of course, makes apparent the intimacy of $19^{\text {th }}$-century Christianity and evolutionary thinking that conceived of non-Europeans as lower races on the evolutionary ladder.

Two things become apparent in this conversation between Broadbent and his interlocutors. The first is obvious and has to do with the fact that Broadbent's translation of the Lord's Prayer aimed to concretize in text the communication of molimo as a Father in heaven and therefore as the figure of presence. Text in this case functions not only to concretize and facilitate the casting of molimo as the Christian God in which case molimo becomes a product of writing as a system of codification, but it also maintains the excavation of molimo from its location in death and the eternal passage (i.e., loss). The connection therefore between writing as affirmation and molimo as something other than presence, became severed in text (the Lord's Prayer in this case). This is the point that is apparent in Broadbent's translation of the Lord's Prayer into Serolong. The second is a more subtle point, but one that is nonetheless connected to the first and concerns the fact that the 
communication of molimo as a 'Father in heaven' is at the same time an attempt to reorder or inaugurate a new way of accounting for creation. These two issues cannot be separated because the communication of molimo as Father in heaven (and therefore as the Christian God) aims to recast anew the question of creation and what other is in the $19^{\text {th }}$-century Southern Africa.

That the communication of molimo as a Father in heaven casts anew the epistemic account of creation in the $19^{\text {th }}$-century Southern Africa, is evident in the difference between Broadbent and his Barolong interlocutors. This difference coheres around the question of the connection between divinity and the work of creation - divinity and what is other. While Broadbent understood and tried to communicate creation as the work of molimo (now cast as the Father in heaven), it is apparent that his interlocutors held a different viewpoint. His interlocutors understood and approached creation as something other than the work of the Father in heaven. This point is made clear in their response to Broadbent that they have never heard of a Father in heaven. This is a crucial point that should not go unnoticed because it implies that while both parties agreed on the connection between divinity and creation, they differed on what the appropriate modality of understanding the connection between divinity and creation should be. Broadbent, on the one hand, advanced a view that claimed that creation is the work of presence. Of course, in this context this means that it is the work of molimo, understood as expunged from death in order to guarantee life. This modality, as a result, accounts for creation on the basis of an expulsion of death.

This is what presence means in this context: It is the expulsion of death from divinity. Broadbent's interlocutors, on the other hand, accounted for creation by claiming that which the Father leaves behind and opposes, namely death. They regarded creation as something other than the work of the Father and therefore of presence. This is a crucial point which suggests that these men engaged Broadbent from the point of view of a radical movement that does not question death. It is this radical movement that the translation of the Lord's Prayer into Serolong tried to nullify. It is rather simplistic and ethnocentric as a result for Broadbent to dismiss his interlocutors as ignorant because they have never heard of a Father in heaven. What should be clear is that their account of creation emanated from an epistemic position that differed from that of his.

The consequence, by Broadbent, of seeing creation via a modality that foregrounds the present sense of time is that it reduces creation and 


\section{Sepetla Molapo}

makes it a product purely of a self-referential model that knows nothing outside itself. This model is blind to exchange and to the extent to which creation is always already a product of exchange (i.e., the exchange of presence with what is anterior to it). Because it is blind to exchange, it is oblivious to the priority of what comes before, what is other. Consequently, only in the form of a totalizing system, it tries to account for creation. Creation, in this case, can only be a consequence of a system of totality in the Levinasian sense (Levinas 1969). This in its own suggests proximity between this model and violence. This is because a model such as this can only derive its existence and legitimacy via a process of incorporation because it does not know a surrender to what is other (and is therefore blind to truth as a product of persuasion). Although in this context this violence is epistemic, it also could result in physical violence in cases where communities resist conversion and incorporation to Christianity, as it was the case during colonization. Indeed, this violence points to the intimacy of race and racism in the $19^{\text {th }}$ century Christian missions in Africa. The radical movement that questions molimo as the figure of presence, opposes this violence because it stands for openness and exchange with what is other.

The account of creation that foregrounds a model of presence, such as the one we see in Broadbent's translation of the Lord's Prayer into Serolong, signals a disregard of an appreciation of the sacred role or function of what is other (what is anterior to presence or the self). Consequently, this model cannot fully mediate the experience of community, if by 'community' we understand exchange with what is other or relationality (Milbank 2003; Nancy 1991; Molapo 2019). This is why it finds in interiority a secure place from which creation can derive its account. Of course, an account of creation that has interiority as its foundation, can only reinforce racial practices because it is a departure from others. Broadbent's model is a model of creation as a construct of an interiority because it is a consequence of the departure of molimo from death and therefore from the materiality of the world $^{4}$. It is a model that has as its basis a Protestant understanding of religion as movement from the outside (from the materiality of religion and therefore from death) to the inside (the devaluation of embodiment) (cf. Asad

4 It is in this regard that we should appreciate Cesaire's critique of Tempels' dematerialization of Bantu philosophy for racial and colonial exploitation (Cesaire 1955:57-58). 
1993). The radical movement that does not question what comes before, on the other hand, represented by Broadbent's interlocutors, appears to have as its foundation, the appreciation of the sacred role of what comes before presence, what is other. Community, or the exchange with what comes before, appears to be precisely the foundation of this movement that Christianity has tried to dissolve. This movement stands opposed to the codification of life which accompanies the casting of molimo as the Christian God. The forgetting of molimo as what is prior to presence, and writing as affirmation, is what Christian texts meant for consumption by $19^{\text {th }}$-century Sotho speakers seeks to achieve. In this way, indigenized Christianity (as is the case with the translation of the Lord's Prayer into Serolong) works against the radical movement that does not question what comes before, even what comes before the present sense of time.

\section{The Rupture of Loss and Love}

In the ultimate end, the centrality of writing as codification to discourse about molimo leads to the rupture of loss and love. This is because, by making molimo available (i.e., by making molimo Father and a figure of presence), writing separates divinity from death and makes death the thing that divinity must overcome in order to secure life. The separation of divinity and death is, among other things, a separation of loss and love because in indigenous African religion, death belongs together with divinity and therefore with loss. As passage, death always points to divinity (i.e., to what is other by virtue of loss). It points to that which is constitutive of experience. If the realm that is constitutive of experience in the world is the realm of others (i.e., others lost to death; the other lost to memory), then such is the realm from whence love issues. This is because as ethical responsibility, love issues as the command of the other. It is the gift of others lost to death and the one lost to memory. As such, love is a demand of loss (i.e., to love is to give what cannot by any means belong to the person as the work of affirmation). Consequently, to love is tantamount to sharing an impossible gift. The circulation of this impossible gift is precisely what ought to comprise human social interactions. This is a gift that cannot be given in the manner of things which one can possess as one's property. 
It may be important to note from the outset that the exit that the elevation of the present sense of time seeks from death, implies a denial of love as a gift of loss and therefore as impossible gift that is nonetheless essential for the imagination of social and political life. This exit is a denial of the prior call of the other (who is lost to death and the one lost to memory) as the prism for the disclosure of the self. It is a movement in opposition to the work of affirmation. The movement that is in response to the prior call of the other is a movement that embraces death because its characteristic feature is the acceptance of the very impossibility of the realization of the self as closure that the present sense of time presupposes. This is because it is presented as open and always in exchange - an exchange that is a response to the prior invitation of the other that selfhood and the fact of being in the world can ever find expression. Love as a gift of loss, as a consequence, concerns sharing with others what cannot derive from the realm of the possible. This sharing entails an outward movement that does not have the self at the center because it is a movement that is a response to the call of the other. Consequently, this is a movement of death (i.e., of loss) from which there is no exit because it renounces the possibility of the realization of the self as closure. Love as a gift of loss as such consists in the intimacy of divinity and death.

In place of love as a gift of loss (or simply the gift of loss), the localization of Christianity places the gift of the Son whose death avails the resources that are necessary for the final overcoming of death in the aftermath of the Day of Judgment. The gift of the Son who has to guarantee divinity's victory over death through a submission to death (sacrificial death), presents an interesting occasion because his death signals a refusal of loss via resurrection. His, nonetheless, is a movement of love and therefore of ethical responsibility towards others, even if it makes love the gift of the possible. Yet, what is remarkable about this love is that it appears to give priority of place to the self over the other. This is because the command to love the other (the neighbor), which the Son issues, has the self as the point of departure. One is commanded to love the neighbor as one loves oneself (Mt 22:39). That the priority lies with the self in this move of love, is apparent. The command to love in this case, even if it is the command of divinity, is devoid of death (i.e., devoid of a recognition of what comes before). Consequently, even as it inspires ethical responsibility, it does so on the terms of the self. The gift of the Son as a result, even if it is the gift of love, remains the gift that does not 
know death (i.e., the priority of what comes before). This is what prevents it from a genuine encounter with the other and otherness ${ }^{5}$ and this is partly why the gift of the Son anticipates the overcoming of death.

If the gift of the Son is the gift of community to the world, as Milbank suggests (Milbank 2003), then the elevation of the present sense of time positions community as something that has to occur in the absence of death. This is to say that community as a construct of the localization of Christianity in the $19^{\text {th }}$-century Southern Africa, emerges as sanitized from loss and passage because it is opposed to death. Consequently, it can only find expression as an abstraction from the real (i.e., passage and loss) because it is as sanitized from death that it finds its expression. It follows as a result that in its Christian expression, community becomes an abstraction from the real. As an abstraction from the real, community retreats from location in the time prior to the present sense of time and finds articulation in space because the elevation of the present sense of time is at the same time the celebration of the priority of space over time (Molapo 2019). In this emerging Christian order, space becomes the new terrain for the articulation of community as the celebration of life as dead. The translation of molimo as the Christian God via writing as codification, consequently, has far-reaching consequences for the experience of community. This retreat from community may have furnished an infrastructure for the exploitative capitalist and colonial practices that have defined and continue to define South Africa's notorious history. Important to also note, is that this retreat of community from death upholds colonial relations that locate colonized subjects together with nature as things to be managed. This is because it is a retreat into racist reason that observes others from the prism of a European ethnocentrism. The conception of personhood, as a result, that this Christian retreat from death assumes, is equally racist.

The proximity between an emerging Christian order in the $19^{\text {th }}$ century Southern Africa, and the order of modernity should not go unnoticed here. That is, if abstraction (i.e., from death) furnishes the basis for a Christian experience of community, then such a community clearly has an affinity to the project of modernity. This is because the project of modernity has as

5 In their own distinct and remarkable ways, Mudimbe (1988) and Said (1978) discuss this point concerning colonial and racial conceptions and practices of otherness. The constellation of religion and race that this paper wants to make in this regard, simply tries to amplify their insights. 


\section{Sepetla Molapo}

one of its foundations an orientation towards the rationale and the abstract. Consequently, it is opposed to what passes and is without secure foundation (i.e., embodiment). This is why, as others point out (Milbank 2003; Pickstock 1998), it is oriented towards the formal and the abstract. Milbank argues that this orientation towards the formal and abstract finds its main expression in the market mechanism that reduces everything into a commodity. The orientation towards abstraction means that both Christianity and the project of modernity share an inclination towards utility and the life of a project. They are both an elevation of the present sense of time. This is despite the fact that Christianity, as Milbank (2003) depicts it, can still provide ground for the critique of capitalism and therefore of the project of modernity itself.

Importantly, the present sense of time does not only serve to create a chasm between love and loss, but it becomes the frame and the very basis around which Christian life becomes constituted. Conversion to Christianity on the part of the $19^{\text {th }}$-century Sotho speakers, as a result, suggests embracing the present sense of time as a modality of temporality informing a new social, cultural, and political order in Southern Africa. This further implies that a conversion to Christianity coincides with and reinforces the authority of the question. That is, the elevation of the present sense of time evident in a conversion to Christianity, is in harmony with a philosophical approach that conceives of reality on the basis of the essences that constitute it. The consequence of this approach, among other things, is the valorization of ethnocentrism. Mudimbe furnishes a critique of this approach with regards to the Western European thought and its Greek heritage (Orrells 2015). The significance of this coincidence, as a consequence, is that it implies that the roots of modernity in Southern Africa lie in the localization of Christianity by European Christian missionaries ${ }^{6}$. The coincidence of Christianity with commerce and the course of civilization ought to be understood against this backdrop. They all cohere around the elevation of the present sense of time.

6 While it can be stated that modernity in Southern Africa must be comprehended in relation to the expansion of colonial empires and their mercantilist forms of capitalism, this essay is of the view that the anchoring of the experience of modernity in the lives of Africans cannot be thought of in the absence of Christianity and the resources that it made possible. Christianity's capture of the body and mind of the Africans has done what guns and money could possibly not manage to do. 
With the new and emerging Christian order of things, as we have already shown, death becomes the enemy that the divinity must overcome in order for humanity to experience unity with the divinity. Nancy (1991) argues that this desire for unity with the divine - or what he calls 'communion' informs the orientation of the Western social and political thought and its tendency for nostalgia when confronted with the alienation of modernity. This is precisely what the Day of Judgment anticipates: A community with divinity outside of death and therefore outside of time as we now know it. This lust for communion with divinity announces not only that death is undesirable but conveys the judgment which Christianity places on the violent act of bodies that have to perish ${ }^{7}$. This violence is of course regarded as a consequence of the fall and therefore the work of evil. As the work of evil, the violence, evident in dying bodies, bears testimony to an alienation from divinity and it is precisely this alienation that the Day of Judgment aims to overcome. In the final analysis, therefore, the elevation of the present sense of time concerns itself with the judgment of violence and the possibility of its dissolution.

If we consider that the elevation of the present sense of time results in the judgment of violence (the violence of bodies that have to perish), we may say that the priority of the present sense of time opens up a coincidence between violence and the authority of the question. This is to say that, while we are in the waiting room (awaiting final victory of life over death), the question of life has to be surrendered to the authority of the question. This is because perishing bodies do not only bear testimony to the invasion of life by death but raise the importance of intervening in life in order to minimize the cruelty of nature on mortal bodies. Intervening in life in order to restrain the brutality of nature appears to be precisely what articulates the connection between the elevation of the present sense of time and the authority of the question. This may perhaps furnish an interesting backdrop against which the intimacy of Christianity and health institutions in the $19^{\text {th }}$-century Southern Africa may be appreciated. Christianity, particularly its relation to the

7 In her path-breaking work, Sylvia Wynter (1995) identifies the binary division between spirit and flesh as central to the Christian conception of difference and the legitimization of violence enacted on bodies. Upon this oppositional model rests the entanglements of race and religion in the modern era. 
institution of health, may be read as an enterprise seeking temporary relief from the terrorism of death while we await the final divine solution.

\section{Conclusion}

This essay has attempted to explore the interaction between Sotho speakers and Protestant Christian missionaries in the $19^{\text {th }}$-century Southern Africa. It has entered this exploration via a critical examination of the dialectical relation between writing as affirmation and writing as a system of codification. It has argued that because the localization of Christianity relies on a process of writing about molimo, it removes molimo from passage to space wherein molimo legitimizes the inauguration of the present sense of time as the time that underscores and announces the advent of a Christian era. The consequence, of course, of this transition is the delegitimization of writing as affirmation and the associated conception of personhood as a construct of loss. Writing as affirmation becomes delegitimized, primarily because the Christian process of writing molimo separates divinity from death and makes the latter the thing that the former must overcome. It is this separation of molimo from death that stands in stark contrast to indigenous African religion that the Protestant Christian missionaries tried to dissolve.

One of the key concerns of exploring the tussle between writing as codification and writing as affirmation, has been to question the dominance of a metaphysics of absence, which continues to structure the experience of the world of the African other of this metaphysics, even beyond direct colonization. The aim of this essay is that this questioning may further contribute to a process that seeks to cut loose the stammering tongue of the African from the dominant Western metaphysics and epistemology, which continues to inform his/her existence. The main other of this dominant metaphysics and epistemology remains the adherent of indigenous African religion that remains generally neglected by the academy and intellectual discourse at large. Cutting loose the African other's stammering tongue in the face of this dominance, however, does not presuppose a return to a genuine African thought system, but is rather an invitation to a critical engagement of the modern legacy which, because of colonization, has become the heritage of the same African other. The important issue is that an engagement with the modern legacy must take seriously the African archive which indigenous 
African religion exemplifies, if we are to make diversity, epistemic and otherwise, the cornerstone of imagining a better humane world after direct colonization.

\section{References}

Asad, T. 1993. Genealogies of religion: Discipline and reasons of power in Christianity and Islam. Baltimore: Johns Hopkins University Press.

Broadbent, S. 1865. A narrative of the first introduction of Christianity amongst the Barolong tribe of Bechuanas, South Africa: With a brief summary of the subsequent history of the Wesleyan mission to the same people. London: Wesleyan Mission Press.

Cesaire, E. 1955. Discourse on colonialism. Pinkham, J. (trans.). New York: Monthly Review Press.

Kagame, A. 1956. La philosophie bantu-rwandaise de l'etre. Brussels: Royal Academy of Overseas Sciences.

Kolsky, E. 2005. Codification and the rule of colonial difference: Criminal procedure in British India. Law and History Review 23, 3: 631-683.

Levinas, E. 1969. Totality and infinity: An essay on exteriority. Alphonso, L. (trans.). Dordrecht: Kluwer.

Magesa, L. 1997. African religion: The moral traditions of abundant life. Maryknoll: Orbis Books.

Manyeli, T. 1995. Phenomenological perspective of Basotho religion. Mazenod: Mazenod Institute.

Mauss, M. 1954. The gift: The form and reason for exchange in archaic societies. London: Routledge.

Mbiti, J.S. 1990. African religions and philosophy. Oxford: Heinemann.

Mignolo, W. 2003. The darker side of the renaissance: Literacy, territoriality and colonization. Ann Arbor: University of Michigan Press.

Milbank, J. 2003. Being reconciled: Ontology and pardon. London: Routledge.

Moffat, J. 1842. Missionary labours and scenes in South Africa. London: John Snow.

Mokoena, D.A. 1998. Sesotho made easy. Pretoria: J.L. Van Schaik. 
Molapo, S. 2019. Cast as written: Protestant missionaries and their translation of molimo as the Christian God in $19^{\text {th }}$-century Southern Africa. Journal for the Study of Religion 32, 1: 4-16.

Mudimbe, Y.V. 1988. The invention of Africa: Gnosis, philosophy and the order of knowledge. Bloomington: Indiana University Press.

Mudimbe, Y.V. 1994. The idea of Africa. Bloomington: Indiana University Press.

Nancy, J.L. 1991. The inoperative community. Minneapolis: University of Minnesota Press.

Ngũgĩ wa Thiong'o. 1981. Decolonising the mind: The politics of language in African literature. Nairobi: East African Educational Publishers.

Orrells, D. 2015. Oedipus in Africa: Mudimbe and classical antiquity. International Journal of Francophone Studies 18, 2-3: 235-262.

Pickstock, C. 1998. After-writing: On the liturgical consummation of philosophy. Oxford: Blackwell Publishing.

Said, E. 1978. Orientalism. New York: Vintage Books.

Setiloane, M.G. 1976. The image of God among the Sotho-Tswana. Rotterdam: Balkema.

Setiloane, M.G. 1986. Africa theology: An introduction. Johannesburg: Skotaville Publishers.

Shepherd, A.W. 2014. The gift of the other: Levinas, Derrida, and a theology of hospitality. Cambridge: James Clarke \& Co.

Temples, P.P.R. 1945. La philosophie bantoue. Elisabethville: Lovanie.

Wynter, S. 1995. Race, discourse, and the origin of the Americas: A new world view. Washington D.C.: Smithsonian.

Dr Sepetla Molapo Academic Department Faculty of Humanities University of Pretoria sepetla.molapo@up.ac.za 